\title{
The Nexus of Statutory Allocation to the Public Water Sector and Population Density of Nigerian States
}

\author{
Samuel I. Egwunatum, and Ambrose O. Ogbeh
}

\begin{abstract}
This paper posits that lack of maintenance, planning and bad governance including corruption led to the failure of the Nigerian public water supply system. A reconnaissance literature survey showed that virtually every city has decayed public taps and infrastructure causing most rural dwellers to trek long distances to obtain water for use with spurious quality. These are inspite of grants and interventions from international donors and credit agencies including the World Bank. Against this backdrop, an investigation was caused to examine the correspondence between financial allocation to the sector and every swelling population. Using analysis of variance for a test population of 20 states from the 36 states in Nigeria with data from National Bureau of Statistics and National Planning Commission, results showed that linearity of statutory allocation was positive with the population density of states with $R^{2}$ values at $<10 \%$. Also, financial allocations to water supply over the period (1994 1996) were unstable occasioned by political and economic instability in the country. Further, the study observed that the epileptic water supply gave to private participation to provide portable drinking water which was hitherto aliento developing economies. The paper recommends that state governments should adopt a responsive model that will adjust allocations to water projects.
\end{abstract}

Index Terms-Financial Allocation; Population Density; Rural and Urban Dwellers; Statutory Allocation.

\section{INTRODUCTION}

Water is one of the resources that is in abundance in Nigeria as observed by [1]. The excess of water has caused erosion and flood in many parts of the country. The distribution of public water supply has not been evenly spread throughout the country. The northern part of Nigeria has been experiencing frequent draught. [2] observed that "water is now the most essential ingredient to human survival and better health. It is difficult to do without water in our country. Improving the quality of water people drink is a duty all of us must work hard to entrench".

[1] stated that the supply of public water to the rural communities and urban areas is not adequate. According to Rural Water Supply and Sanitation (RWSS), water supply means the delivery of 30 litres per capita per day of safe water within 250 meters of the community and serving about $250-500$ persons per water point. [3] opined that several traditional ways of getting water has already been

Published on May 11, 2018. The Nexus of Statutory Allocation to the Public Water Sector and Population Density of Nigerian States.

S.I. Egwunatum is with Delta State Polytechnic, Ozoro. Currently directing the construction economics research group. (e-mail: samuelegwunatum@gmail.com).

A.O. Ogbeh is with Delta State Polytechnic, Ozoro. (e-mail: sammyikinimore@gmail.com). worked on by communities and individuals since several decades and put to use in various areas in our urban and remote towns.

The United Nations Economic Commission for Africa (UNECA) (2012) stated that only $20 \%$ of Nigeria's population has access to public water supply. Furthermore, residents of urban and semi urban areas that have access to water do not have it in sufficient quantities.

The Government of Nigeria for a long time has thought and looked into the issue of providing water supply as the direct responsibility of the Federal, States and Local governments. The public sector has been unable to meet the residential, commercial and public water needs of the people. Out of the 88 million residing in our urban and semi-urban towns, only a negligible percentage has access to public water supply [4]. Some of the poorest households often buy water at costly prices form private businessmen and women. Even where the water exists, its services are epileptic and unstable due to operational hardship and pricing mechanism. Several water supply systems exhibited colossal depreciation of present capacities due to poor maintenance, under utilization and lack of money for further expansion [5];, [6]. This study becomes important in view of the various states' slim financial situation that have limited the allocations to the State Water Agencies (SWAs) thereby making new investment and maintenance impossible.

Governments at state levels have not done enough in meeting the aspirations of the citizen in the provision of water. The people are worried as to why the state governments are finding it difficult to fulfill their constitutional role of providing the essential need for them.

\section{LITERATURE SURVEY}

Available data show that there are enough water resources in the aquifers and at surface level in Nigeria to meet her present need for potable water despite its lack in certain areas of the northern region (USEPA, 1999). These enabled towns in the North to resort to surface water resources with its attendant difficulties in water treatment. In the South, there is the problem of water transfer among the states while along the Delta region and major Nigeria towns, the Nation is contending with erosion and water pollution menace. The previous governments focused only on the development of water resource but neglect its management as a national resource [7]. As vigorously stated by [8], the national water policies that were formulated brought on board River Basin Development Authorities (RBDA) under the FMWR which empowered it for the development of water resources within the basin for proper conservation and utilization of water resources through Decree 101 of 1993. Subsequently, a master plan for the nation to manage and develop its water 
resources came to be with the support of the Japanese Government in 1994 [9]. At present, the Federal Ministry of Water Resources has formed Water Resources Management Strategy (WRMS) for the nation. The functions of the WRMS include the following:

i. Rehabilitation and development of water supply

ii. Protection of water - shed

iii. Management of basins

iv. Management and monitoring of water quality and pollution control

v. Management of international waters management and control of environmental protection and pricing [10][13].

\section{A. Impact of Population in Water Supply System}

The 2006 census placed the population of Nigeria to be $167,912,561$ Nigerians and based on average growth rate of $2.9 \%$, the year 2012 estimate was already above 170 million cutting across the 774 Local Government areas of the 36 states and Abuja (NPC, 2009). Those living in the rural communities are more than half of this population but with poor access to potable water. The United Nations Organisation (UNO, 1976; [14] submitted that the use of potable water should be proportional to the population of the people to be provided with water. Water supply has been defined as "the provision of 30 litres per capita per day of safe water within two hundred and fifty meters $(250 \mathrm{~m})$ of the environment and serving almost two hundred to five hundred persons per water point". The main source of water supply in most of our towns in the Ground water, which is usually difficult to drill. The other main sources of water available are the surface and atmospheric water sources. Water is taken to the people using ground water through the under listed technological options namely hand dug wells, hand pump wells, hand pumps boreholes, electric powered mechanical boreholes and spring development. The surface and atmospheric water sources use the followings: (1) Rain water harvesting (2) Slow and filtration system with infiltration galleries [15- [17]. The same views were expressed by [18] and [19] in the cause of urban deficits in water supply versus the estimated demand by the people. Below is the population distribution

TABLE I: POPULATION DisTRIBUTION ${ }^{1}$

\begin{tabular}{llll}
\hline Type & Community size & $\begin{array}{l}\text { Population } \\
\text { (million) }\end{array}$ & \% of total \\
\hline Urban & $>20,000$ & 45.0 & 38 \\
Small towns & 5,000 to 20,000 & 40.0 & 33 \\
Rural & $<5,000$ & 35.0 & 29 \\
\hline \hline
\end{tabular}

\section{B. Impact of Population Density on Water Resources}

Population density is the population of the people divided by the geographical area of the place where the people live. Nigeria is a highly populated country in Africa. According to the 2006 census, the population density of Nigeria was 184 persons per square kilometer accordingly with a land area of $924,000 \mathrm{~km} 2$ as indicated by [16] and [20] (1989). Population density is also the measure of the weight that is pressed on an area of land by population [16], [21]. This has

${ }^{1}$ Source: National Population Commission, Abuja (2009) National Bureau of Statistics, Abuja. kept several professionals especially geographers wondering for a long time in their quest to know how population density relates with resources in the world especially water. Although Africa is the second smallest continent after Australia, huge water resources exist in Africa. As indicated by [22], [23], [6], population density is the most accepted way of comparison between communities.

Lack of water has led to violence and poor financial management caused by frequent changes in governments [24]. The principle of moving water from areas where there is abundant water but lower usage to where there is low quantity of water and higher demand is as a result of influence of population density. This has been responsible for the transfer of $75 \mathrm{~km}$ Gurara interregional conveyance pipeline project in Niger State to Abuja [24].

\section{Population Density}

Population density is a mathematical ratio derived as the quotient of the population of a locality divided by the geographical areas of the locality. Population density is thus, an indication of the amount of pressure exerted by population in a unit area of land. This pressure has intrigued geographers for a long time, and attempts have been made to derive specific formulae that relate population density to the resources of the earth. Such formulae would provide the critical population density, which is the point at which the pressure exerted on the land by population acts as determinant of further population growth. The carrying capacity of land in such an area would then have been reached. This in effect shows how much population pressure the earth can bear. Of a necessity, such a formula would be location-specific, given the fact that levels of natural resources vary widely from locality to locality [25], [20]. Population density however has some serious shortcomings. A basic assumption of the technique is that the population is evenly distributed. This is rarely the case in real life. Africa has $10 \%$ of world population existing on $22 \%$ of total land area of the world. The population density of the continent is 16 persons per square kilometer, existing on less than half of the 30 million square kilometers of available land area. Large expanses of area are uninhabitable, being dry, sandy or rocky deserts. Attempts to overcome this shortcoming of population density have considered the use of more specific ratios such as:

i. The ratio of inhabitants of an area to the area under human settlement

ii. The ration of inhabitants to the area of land under cultivation

iii. Ratio of school age children to the area of classrooms available.

These ratios show that Africa is the second least populated continent after Australia. In spite of all these shortcomings, population density finds wide acceptance as a useful measure of the pressure exerted by population on the earth for the purposes of comparison between different localities [26], [16], [21]. An important aspect of the concept of population density is that it relates mostly to land and other natural resources. Natural resources such as land, water and solar energy are fixed in the supplies available. There are optimal levels of these resources that a human being requires for normal growth and function. Such levels 
are related to the type of civilization and society that the individual lives in. Affluent societies find more uses of water than impoverished ones, e.g. for land watering, swimming pools. Rapid and uncontrolled increases in the number of people sharing a natural resource in a particular area would thus tend to depress the standard of living of a society. This might be more noticeable in more affluent societies than in poorer areas. One likely solution would be to encourage migration to other less populated areas. The encouragement of farm settlements around the BauchiBorno axis of northern Nigeria through the extension of services of the Nigerian railways to the area provides an instance of the application of this solution in Nigeria. The opening up of the Amazon-drained interior of Brazil through the $6000 \mathrm{~km}$ long Trans-Amazon highways is an effort to decongest the coastal areas, where $90 \%$ of the entire population of the country is concentrated. All the foregoing are official governmental reactions traceable to the recognition of population density as a powerful concept in decision-making that has to do with environmental and natural resources. Those arid lands of the world account for some $33 \%$ of the total land area of the earth. Examples from these lands are those that directly show the influence of population density on: (i) the sourcing, use and conservation of water resources, (ii) government policies concerning environmental and water related issues and (iii) geographical issues [22], [23], [6].

\section{Population Density and National Water Policies}

National Water Policies encourage coherent and coordinated approach towards water resources management. The main objectives of such policies include: (i) optimum utilization of such resources, and (ii) conservation and management of available water resources. Other objectives are (iii) maximization of the benefits deriving from water resources conservation and utilization, (iv) valuation of water, and (v) the satisfaction of present and future water requirements or all purposes [26].

Population density of different areas should feature prominently in National Water Policy. Rapid and sustained increases in the population densities of certain localities might be the signal for water transfer efforts of commence. The allocation of facilities for the provision of potable and irrigation water should also consider the level of need of such localities as indicated by the population pressure. The intensity of social uses of surface water bodies for recreational purposes might be expected to be promotional to the population densities of the surrounding and adjacent localities. In countries with a federal structure, population density will have a bearing on the respective roles of states and the federation with regards to water as stated in the National Water Policy. Some of the issues to be resourced include: The vesting of the control of shared water resources in a single tier of government, The responsibilities of the various governments for the distribution of water resources within their areas of jurisdiction. The availability of such water to needy neighbouring states must be addressed [24]; [27].

\section{RESEARCh METHODOLOGY}

Data was acquired on the following:

1. Average statutory allocations to water projects by each state government

2. Population densities of the states

3. The dependent variables of the study were (i) sizes of population (ii) population density (iii) sizes of geographical areas of the states

4. The independent variables of the study were (i) allocation to water supply in each state (ii) the number of water projects covered by such allocation. The variables were intended to show the trends between population, population density and the statutory allocations to water sectors by state governments.

\section{A. Method of Data Analysis}

The data collected will be analyzed by a Software Package for Social Sciences (SPSS 5.0). The inferential and descriptive methods were used in analysis of the data. The inferential method involved the use of simple regression, multiple regression correlation and Analysis of Variance (ANOVA). The descriptive method involved data being classified in tables under minimum, maximum, mean, standard deviation. Data employing descriptive statistics were reduced for easier interpretation by charts and graphs. All experiments were guided by certain criteria employing statistical techniques. These were as follows: (i) the null hypothesis (ii) the calculated value of "F" for the selected test statistics corresponding to the sample size, number of variables and level of probability used and (iii) the calculated value of the test statistics.

\section{B. Presentation of Data, Results and Discussions}

\section{1) Statutory Allocation for Water Projects (1994-196)}

TABLE II: RAW DATA USED FOR THE STUDY ${ }^{2}$

\begin{tabular}{llclll}
\hline \hline S/ & State & $\begin{array}{c}\text { No of } \\
\text { proje } \\
\text { ct }\end{array}$ & $\begin{array}{l}\text { Average } \\
\text { Allocation } \\
\text { (N) Million }\end{array}$ & Population & $\begin{array}{l}\text { Population } \\
\text { Density } \\
\text { (No } \\
\text { pers/Km } \mathbf{K}^{2}\end{array}$ \\
\hline 1 & Abia & 1 & 86.28 & $2,842,980$ & 449.83 \\
2 & Adamawa & 7 & 15.92 & $2,102,053$ & 56.93 \\
3 & Akwa Ibom & 4 & 18.44 & $2,929,086$ & 413.62 \\
4 & Anambra & 16 & 54.84 & $3,399,773$ & 701.85 \\
5 & Benue & 1 & 29.33 & $2,756,077$ & 80.83 \\
6 & Cross River & 4 & 126.96 & $2,323,629$ & 115.28 \\
7 & Delta & 4 & 41.66 & $3,124,647$ & 176.55 \\
8 & Edo & 5 & 34.57 & $2,625,800$ & 147.50 \\
9 & Enugu & 2 & 94.95 & $3,834,890$ & 503.41 \\
10 & Katsina & 4 & 41.14 & $3,753,3$ & 155.13 \\
11 & Kebbi & 8 & 109.32 & $2,068,490$ & 56.220 \\
12 & Kogi & 5 & 25.45 & $2,147,756$ & 71.99 \\
13 & Kwara & 1 & 27.17 & $1,548,412$ & 42.04 \\
14 & Niger & 3 & 43.30 & $2,421,581$ & 31.71 \\
15 & Osun & 9 & 57.05 & $2,158,143$ & 233.28 \\
16 & Oyo & 8 & 48.53 & $3,452,720$ & 121.34 \\
17 & Plateau & 4 & 48.53 & $2,104,536$ & 36.26 \\
18 & Rivers & 1 & 20.53 & $5,239,315$ & 597.78 \\
19 & Sokoto & 10 & 18.53 & $2,397,000$ & 36.46 \\
20 & Taraba & 4 & 44.62 & $1,515,163$ & 27.75 \\
& Total & 100 & 1059.66 & $54,739,184$ & 4024.16 \\
\hline \hline
\end{tabular}

${ }^{2}$ Sources: National Planning (1993) National Rolling Plan 1994-96, National Planning Commission, Abuja, Nigerian Federal Office of Statistics (1993) 


\section{2) Allocation to Water Supply by States}

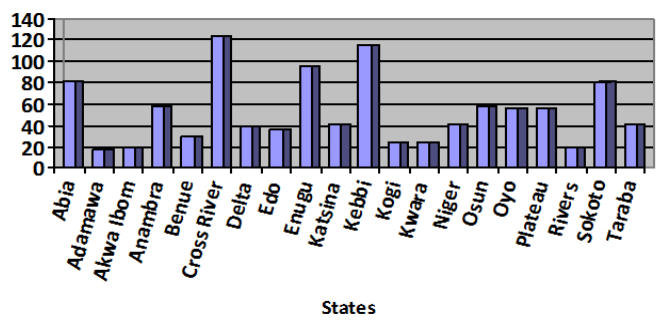

Fig. 1. Allocations to the water supply sector in Nigeria (1994-1996)

The followings points out the main characteristics in Fig. 1, Cross River State has the highest average allocation of N127 million naira while Adamawa State has the lowest is N18 million naira. When allocations were superimposed on population, both of them showed inconsistency with each other after their testing.

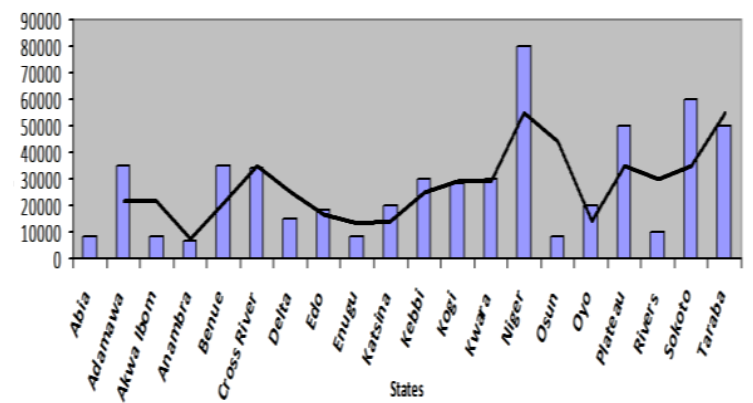

Fig. 2. Graph of population and allocations to water supply in 20 selected sates of Nigeria (1994-1996)

There was no consistency in the allocation to water projects and population of the various states. The population of Cross River that has the highest amount of money or the allocation is 134 persons per square kilometer which was below average in comparison to the average population density of 264 persons per square kilometer.

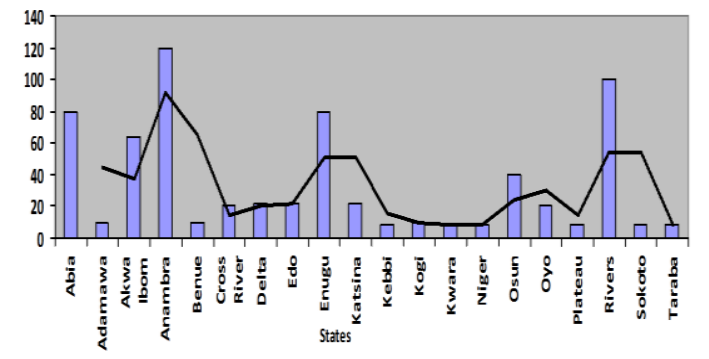

Fig. 3. Graph of population densities and allocations to water supply in 20 selected sates of Nigeria (1994-1996)

The following were the main features in Fig. 3. There was no consistency in the average allocation to water projects and population density of the states. The population density of Cross River had the highest amount of allocation of water supply section.

\section{a) Number of Water supply Projects}

The following were the main issues in Table II. The numbers of projects embarked upon were between 1 and 16 . Rivers State was one of the sates with the smallest number of water projects (1). Anambra State had the highest with 16 numbers. There were no consistency noticed with population and the number of project embarked upon in the states. The highest population was Oyo Sate among the highest number of water supply projects also (8).

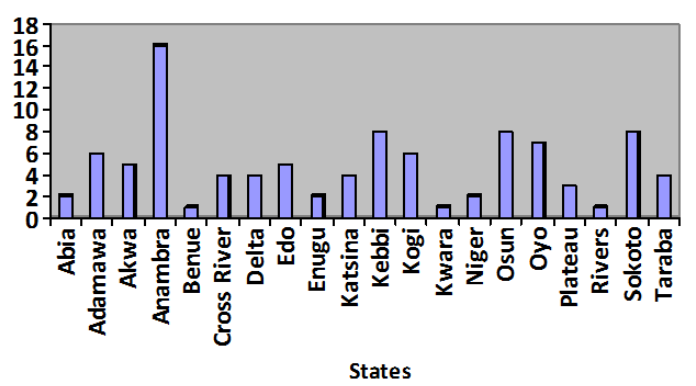

Fig. 4. Population Densities and number of water supply in 20 selected sates of Nigeria (1994-1996)

The following main points were noticed in Fig 4. Anambra State had the highest figure for the number of project (16) and population density (701.85) persons $/ \mathrm{km}^{2}$. Sates with lower population densities had more water projects.

\section{b) Population}

Fig. 5 below shows a bar chat of the value of populations of selected states of Nigeria. Maximum and minimum values were 5,239,315 and 1,512,163 for Rivers and Kwara States respectively. Generally, higher population/household figure occurred in southern states than in the northern part had a population in excess of three million persons.

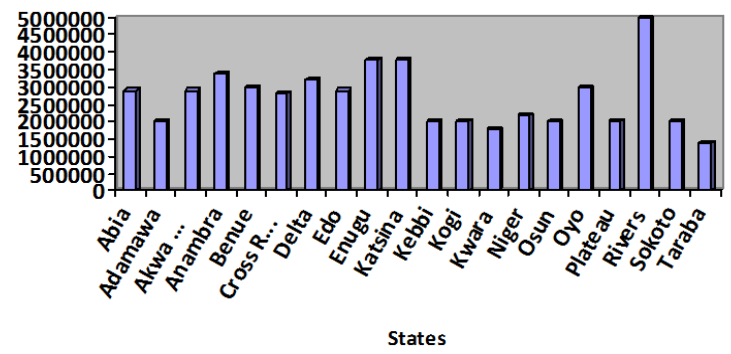

Fig. 5. Population of some selected sates of Nigeria (1994-1996)

\section{c) Population Density}

Fig. 5 showed that average population density were 593.5 and 346.05 persons per square meter respectively northern and southern states. The overall average for both northern and southern states was 202.79 persons per square $\mathrm{km}$. The range of values lay between 27.8 and 701.8 persons per square $\mathrm{km}$. Anambra State had the highest population density (701.85), Taraba State had the lowest (27.75). Only four southern states had population densities below the national average.

d) Summary of Descriptive Analysis

Population (Fig 5): southern states had the highest population figures (Rivers State, 5,239,315 persons, followed by Enugu State, 3,834,890 persons). Among the northern states, only Katsina State had a population in excess of three million persons $(3,753,13)$.

Population density (Fig 5) Average population densities nationally and in northern and southern states were 202.79, 59.5 and 36.05 persons per square $\mathrm{km}$ respectively. Only 
four southern states had population densities less than the national average: Cross River (115.28) Delta (176.55) Oyo (121.34). Values for all northern states were below the national average.

\section{INFERENTIAL ANALYSIS OF RESEARCH DATA}

This research data made use of inferential statistical analysis and ANOVA as testing tools.

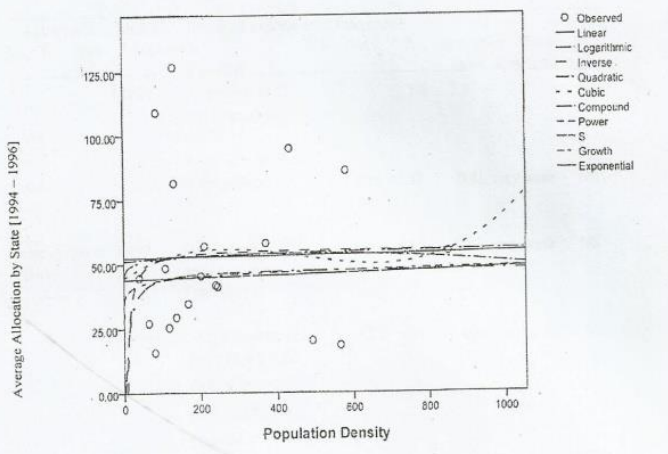

Fig. 6. Scatter plots of population density of states versus average allocation by states

\begin{tabular}{|c|c|c|c|c|c|c|c|c|c|}
\hline \multirow[t]{2}{*}{ S/No } & \multicolumn{2}{|c|}{ Variable type } & \multirow{2}{*}{$\begin{array}{l}\text { Model } \\
\text { Regression }\end{array}$} & \multirow{2}{*}{$\begin{array}{l}\text { Result of experiment } \\
\text { Equation }\end{array}$} & \multicolumn{3}{|c|}{ Inference } & \multirow{2}{*}{$\begin{array}{l}\text { Strength of } \\
\text { Value }\end{array}$} & \multirow{2}{*}{$\begin{array}{l}\text { Rank } \\
\text { Relationship }\end{array}$} \\
\hline & $\mathbf{x}$ & $\mathbf{Y}$ & & & R2\% & Net F & $\mathbf{P}$ & & \\
\hline $4.2 \mathrm{a}$ & & & Linear & $\begin{array}{l}\text { Avgalloc }=48.12+ \\
0.0032 \text { Popn Dsty }\end{array}$ & 1.0 & 5.47 & 0.8 & Very weak & NS \\
\hline $4.2 \mathrm{~b}$ & & & Logarithmic & $\begin{array}{l}\text { Avgalloc }=45.33 \\
+1.44 \text { PopnDsty }\end{array}$ & 2.30 & 3.48 & 0.41 & Very weak & NS \\
\hline $4.2 \mathrm{c}$ & $\begin{array}{l}\text { popn } \\
\text { Dsty }\end{array}$ & Avgalloc & Quadratic & $\begin{array}{l}\text { Avgalloc }=47.48^{\mathrm{E} 05} \\
\text { Popn Dsty- } 6.46 \\
\text { Popn Dsty }\end{array}$ & 0.64 & 4.47 & 0.83 & Very weak & NS \\
\hline $4.2 \mathrm{~d}$ & & & Cubic & $\begin{array}{l}\text { Avgalloc }=48.32 \\
\text { Popn Dsty }+0.21 \\
\text { Popn Dsty*-132 } \\
\text { PopnDsty*+6.41 } \\
\text { popn Dsty** }\end{array}$ & 1.87 & 4.51 & 0.98 & Very weak & NS \\
\hline
\end{tabular}

Key NS = Not Significant

\section{A. Observation and Inferences}

Below were the observations and inferences in respect of population density and allocation as in Table II.

$\mathrm{R}^{2}$ values from $0.64 \%$ to $1.87 \%$

A state with population density of 150 persons per square kilometer allocated 58 million naira to water supply over the three-year period (1994 - 1996).

Probability values not above 0.05 limit (5\% level of significant)

The results showed that increase in population density leads to corresponding increase in allocations by state governments to the water sector.

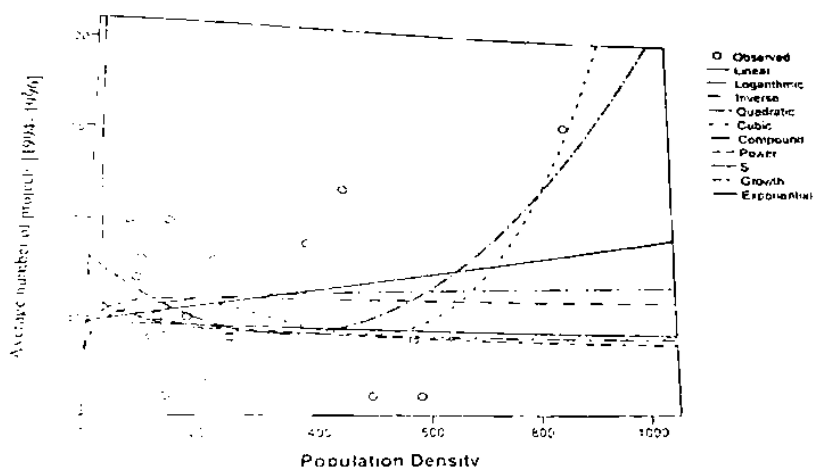

Fig. 7. Scatter plots of population density of state versus average number of projects

TABLE IV: RESULT OF (IMPACT OF POPULATION DENSITY ON NUMBER OF PROJECTS)

\begin{tabular}{|c|c|c|c|c|c|c|c|c|c|}
\hline \multirow[t]{2}{*}{ S/No } & \multicolumn{2}{|c|}{ Variable type } & \multirow{2}{*}{$\begin{array}{l}\text { Model } \\
\text { Regression }\end{array}$} & \multirow{2}{*}{$\begin{array}{l}\text { Result of experiment } \\
\text { Equation }\end{array}$} & \multicolumn{3}{|c|}{ Inference } & \multirow{2}{*}{$\begin{array}{l}\text { Strength of } \\
\text { Value }\end{array}$} & \multirow{2}{*}{$\begin{array}{l}\text { Rank } \\
\text { Relationship }\end{array}$} \\
\hline & $\mathbf{X}$ & $\mathbf{Y}$ & & & $\mathbf{R} 2 \%$ & Net F & $\mathbf{P}$ & & \\
\hline $4.3 \mathrm{a}$ & & & Linear & Avgalloc $=3.48+$ & 2.80 & 6.11 & 1.49 & Very weak & NS \\
\hline $4.3 b$ & & & Logarithmic & $\begin{array}{l}\text { Avgalloc }=2.28+48 \\
+0.00028 \text { popnDsty } \\
\text { PopnDsty }\end{array}$ & 2.40 & 6.11 & 0.78 & Very weak & NS \\
\hline $432 \mathrm{c}$ & $\begin{array}{l}\text { popn } \\
\text { Dsty }\end{array}$ & Avgprojc & Quadratic & $\begin{array}{l}\text { Avgalloc }=4.86+0.3 \\
\text { Popn Dsty }+3.273417 \\
\text { E-0.5popn Dsty }\end{array}$ & 19.07 & 4.68 & 0.17 & Very weak & NS \\
\hline $4.3 \mathrm{~d}$ & & & Cubic & $\begin{array}{l}\text { Avgproj=2.18+0.47 } \\
\text { Popn Dsty-0001 } \\
\text { Popn Dsty- } \\
\text { 2.8646502E06popnDsty* }\end{array}$ & 59.78 & 4.66 & 0.001 & Fair & NS \\
\hline
\end{tabular}

Key NS = Not Significant

\section{B. Observation and Inferences}

Below were the observations and inferences in respect of population density number of projects in Table III. Weak and positive correlation existed 
$\mathrm{R}^{2}$ values were $2.80 \%$ and $2.04 \%$ and $19.07 \%$ respectively under linear, logarithmic and quadratic regression. Strong correlation under cubic with $\mathrm{R}^{2}$ of $59.78 \%$,

States having population density of 1000 people per square kilometer embarked on 8 water supply projects within the period $1994-1996$. The result showed that when there is increase in population within a state, the number of projects would also increase due to the positive linearity.

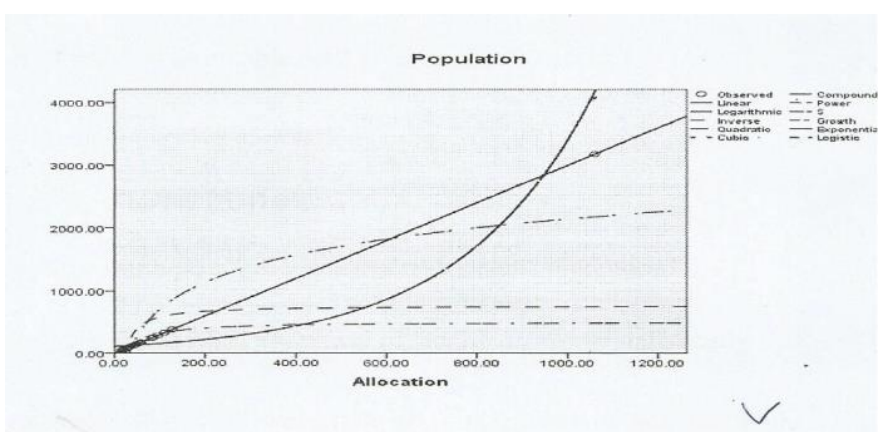

Fig. 8: Population density versus number of projects

TABLE V: Result (Impact of Population Density on Number of projects)

\begin{tabular}{|c|c|c|c|c|c|c|c|c|c|}
\hline S/No & \multicolumn{2}{|c|}{ Variable type } & $\begin{array}{l}\text { Model } \\
\text { Regression }\end{array}$ & $\begin{array}{l}\text { Result of experiment } \\
\text { Equation }\end{array}$ & \multicolumn{3}{|c|}{ Inference } & $\begin{array}{l}\text { Strength of } \\
\text { Value }\end{array}$ & $\begin{array}{l}\text { Rank } \\
\text { Relationship }\end{array}$ \\
\hline $4.4 \mathrm{a}$ & & & Linear & $\begin{array}{l}\text { NprojWs =14.3- } \\
0.00244 \text { NPDsty }\end{array}$ & 2.30 & 6.36 & 0.63 & Very weak & NS \\
\hline $4.4 \mathrm{~b}$ & & & Logarithmic & $\begin{array}{l}\text { NprojWs c=5.18-32 } \\
\text { NPDsty }\end{array}$ & 0.46 & 4.11 & 0.59 & Very weak & NS \\
\hline $4.4 \mathrm{c}$ & Npopna & NprojWs & Quadratic & $\begin{array}{l}\text { NprojWs }=14.33361 \\
\text { E-05NpDsty-0.14 } \\
\text { NPDsty+4.3464123 } \\
\text { E-05 }\end{array}$ & 23.18 & 6.18 & 0.73 & Very weak & NS \\
\hline $4.4 \mathrm{~d}$ & & & Cubic & $\begin{array}{l}\text { NprojWs }=6.287+1 \\
\text { 03NPDsty+0.2313 } \\
\text { NPDsty }\end{array}$ & 2.24 & 6.31 & 0.82 & Very weak & NS \\
\hline 44ai & & & Linear & $\begin{array}{l}\text { SprojWs=2.74-28 } \\
\text { SPDsty }\end{array}$ & 2.18 & 5.40 & 0.87 & Very weak & NS \\
\hline $4.4 \mathrm{bi}$ & & & $\log$ & SPDsty & 0.03 & 4.22 & 0.63 & Very weak & NS \\
\hline $4.4 \mathrm{ci}$ & spDsty & NprojWs & Quadratic & $\begin{array}{l}\text { SprojWs }=12.68- \\
\text { 06SPDsty }+8.215 \\
7011 \text { E-05 } \\
\text { SPDsty* }\end{array}$ & 47.04 & 5.80 & 0.46 & Very weak & NS \\
\hline 4.4di & & & Cubic & $\begin{array}{l}\text { SprojWs }=9.84+18 \\
\text { SPDsty-0.007 } \\
\text { SPDsty+58661235 } \\
\text { E-07 SPDsty }\end{array}$ & 84.93 & 5.78 & 0.42 & Very weak & NS \\
\hline
\end{tabular}

Key NS = Not Significant

\section{Observation and Inferences}

Below were the observations and inferences in respect of population density number of projects inTable $\mathrm{V}$ (NorthSouth).

Very weak and negative correlation

$\mathrm{R}^{2}$ values were below $25.414 \%$

$\mathrm{R}^{2}$ values for southern states was $84 \%$ under cubic regression

$\mathrm{P}$ value, were above $0.05(5 \%)$ level of significant, level statistically.

This suggested that there were reduction in number of projects while the population density of northern states increase

\section{RESULTS AND DISCUSSION}

Based on the outcome of the results, the number of people (population) and population density within the northern and southern regions had inverse proportionality to statutory allocations and the number of water supply projects in northern states.

Low $\mathrm{R}^{2}$ values of $14 \%-36 \%$ were recorded for the states in the south with the exception of population density of $84 \%$. In the south also, statutory allocation and numbers of water supply projects had inverse relationship with sizes of population and population density. However, the relationship between population density and the number of public water supply projects were directly proportional as in experiments 4.5 and 4.6. Invariably, states with bigger populations in the south allocated little finance to water supply projects but embarked on larger numbers of water projects in contrast to their non-populated neigbours, the low $\mathrm{R}^{2}$ values of $36 \%$ showed that there were gross changes and inconsistency in the amount of money and number of projects over the years of the study period.

Governments do not pay particular attention to how growth influences population and its distribution pattern because of political reasons do invite water scarcity unfailingly. Furthermore, bigger states both in geographical areas and population did not budget much money to water supply projects in accordance to the size of their population and geographical area as in the case of Niger State. The reasons for this are not farfetched. The sharing of money for capital projects in Nigeria is based on revenue, indication accruing to the federal government but had not been given much emphasis.

\section{SUMMARY}

The study established the relationship between National Rolling Plan executed completely. Pilot surveys from ten states of Nigeria have suggested that between reoccurs allocation for water supply by the public sector within their various states. Correlations existed between funding of water supply and the population, population density and geographical area of states in the region. 
The literature review highlighted that between 19941996, the three-year period of the study, over N87 billion was spent on water supply. Much important was attached to agricultural use of water throughout the country and even globally too. Developing countries especially Africa do not encourage privatization of water supply buy their private investors as in developed countries [28].

Huge water resources exist under aquifers underground is 100 times the amount found on the surface (BBC Science reporter, 2012). Demand for water is to set grow high higher in the coming decades due to population growth and the need for irrigation to grow crops. Based on the data from twenty states, experiments were conducted. The outcome of data results provided that statutory allocations by states fluctuated by wider margins with a mean value of 54 million naira. Number of projects had inverse relationship with allocation and population density in the south $\mathrm{R}^{2}$ values of $14 \$-36 \%$ were recorded in the south except population density that had $84 \%$.

Conclusively, the outcome of the analysis showed that population failed to play significant impact on financial allocation and number of water projects embarked upon by state governments. Minimal impact on allocations by population density. $\mathrm{R}^{2}$ is less than $4 \%$. The outcome totally agreed with majority opinion that financial allocations under-mind area of need like population, population density and geographical area in Nigeria.

\section{CONCLUSION}

During the study period of 1994-1996, allocations to water supply sector decreased as the population increased in the states as observed from the negative linearity and $\mathrm{R}^{2}$ values of $6.85 \%$.This was evidently clear as states with larger population gave smaller amount of money to water supply sector than stares with little population. A positive linearity of $\mathrm{R}^{2}$ values of $0.007 \%$ was recorded against population density. This showed that densely populated states gave more to water supply sector financially compared to the less populated states. Statutory allocations to water supply had inverse relationship with geographical areas. During the period of the study, the number of water supply projects decreased as the population of the states increased as seen from the $\mathrm{R}^{2}$ values of $0.062 \%$ i.e. the numbers also $\left(\mathrm{R}^{2}=0.38 \%\right)$.

\section{RECOMMENDATION}

It was recommended that funds for water supply at the state levels be increased and promptly released by either the external support agencies or the private sector for optimal use. There is the need for the formulation of national rural water supply framework. This will ensure that water supply activities are effectively coordinated. The federal, state and local government areas should align with human rights and partnership approach which advocates working with communities for the improvement of their various water supply systems.

\section{REFERENCES}

[1]. World Health Organisation. World Development Report., Washington DC USA, 2004
[1]. M. Pate. Portable Water: between profit-making and quality healthcare. This Day Newspaper, Tuesday February 28, 2012 p21.

[2]. A.K. Howard. Supply. Waste Disposal and Environmental Engineering Khanna Publishers, Delhi. 2000 p .776

[3]. E. Dean. Plan Implementation in Nigeria 1962 - 66; Ibadan, Nigeria, 1972. Oxford University Press, p. 23.

[4]. C. Agnew and E. Anderson. Water resources in the arid real. London: UK. 1992, Routledge, p. 238

[5]. B.G. Applegren, (Eds). (1996). A management approach to national water scarcity. In P. Howeson and R.C. Carter Water policy: allocation and management in practice. London: UK, E \& FN Spon, 1976 p. 61

[6]. L.J. Abrams. Policy development in the water sector - the South African Experience. In P. Howson and R.C. Carter Water policy: allocation and management in practice. London: UK, E \& FN Spon, 1996.

[7]. L. Oyebade. Water resources in H.I. Ajaegbu, B.J. St. Matthew Daniel and O.E. Uya (eds) Nigeria: a people united, a future assured. Vol. 1, Abuja, Nigeria Federal Ministry of Information, Abuja, 2000 p.83-90

[8]. E.A. Ojo. "An Open Reply to the Attack on the Water Corporation of Oyo State ion the floor of the Oyo State House of Assembly" Ibadan, 1980, Nigeria. The Punch, 7 Jan., p.7

[9]. J. Winpenny. Managing water as an economic resource. London: UK; Routledge, 1994B p. 1-2.

[10]. P.R, Reynolds. The water grid concept. In. G.N. Goluber and A.K Biswas (eds) Interregional water transfers: problems and prospects. Oxford, UK; Pergamon Press; 1978awater development, supply and management series, volume 6 o. 147-152.;

[11]. G.N. Golubev and A.K. Biswas, (eds) Interregional water transfers: problems and prospects. Oxford, UK; Pergamon Press; water development, supply and management series, volume 6 p. 63.

[12]. FGN/JICA,, (1994). The study on the national water resources master plan (NWRMP) Draft final report: water resources inventory survey (volume 111). Federal Ministry of Water Resources and Rural Development/Japan International Cooperation Agency, Nigeria p. 215244.

[13]. C.H. Green. Water and economics - what does experience teach us so far? In P. Howson and R.C. Carter Water policy: allocation and management in practice. London: UK, 1991. E \& FN Spon, p.42.

[14]. T.E. Hilton. Practical Geography in Africa. Essex, UK, 1961 Longman Group Ltd. P.117.

[15]. J.I. Clarke. Population Geography and the Developing countries Oxford: Pergamon Press Ltd., 1971a P. 1-2.

[16]. A.G, Onokerhoraye. An outline of Human Geography. Geography and Planning Series of Study Notes; Benin, 1985, Nigeria p. 111.

[17]. A.O. Adedeji. Nigeria Federal Finance,. Ibadan: Oxford University Press, 1969.

[18]. J.I. Clarke. Population Geography and the Developing countries Oxford: Pergamon Press Ltd., 1971b P. 19.

[19]. J.I. Clarke. Population Geography and the Developing countries. Oxford: Pergamon Press Ltd., 1971c P. 36.

[20]. J.I. Clarke. An advanced Geography of Africa. Amersham: Hulton Education Publishing Ltd., 1975a P. 115

[21]. R.J. Harrison - Church, J.I. Clarke, P.J.H. Clarke and H.J.R Henderson. . Africa and the Islands.,Fourth edition, Geographies, an intermediate series; London, UK , 1977. Longman Group Ltd. P 68 69

[22]. B. Mitchell. Geography and Resources Analysis. Second Edition, Essex UK, Longman Scientific and Technical, 1989,,p.156-157

[23]. B.W. Hodder . Economic Development in the tropics., Methuen Inc., New York, USA, 1980. Third Edition p. 2-253

[24]. B. Knapp, S. Ross and D. McCrae. Challenge of the Economic Environment.,Essex, UK; Longman Group UK Ltd (Earthscpae Edition) 1989, p. 258

[25]. H.D. Clout. Rural geography: an introductory survey. England: Oxford, 1972.,Permagon press P. 110-112.

[26]. A.N. Strahler,and A.H. Strahler.,Geography and man's environment., New York: USA 1978. John Wiley and Sons Inc. p. 168.

[27]. UNWC, 1977. Conference recommendations (the mar del plate Action Plan), Mar del Plata, Argentina, 14 March 25, the United Nations; cited in Biswas, K.A. (1978) 'Mal del Plata, Action Plan?,In K.A. Biswas (ed) United Nations Water Conference: summary and main documents. Water development supply and management series, Vol. 2, Oxford UK. Pergamon Press U.N.O. p. 165.

[28]. S.A.Postel. United Nations Water Conference: summary and main documents. Water development supply and management series, Vol. 2 , Oxford UK. Pergamon Press, 1992 U.N.O. 


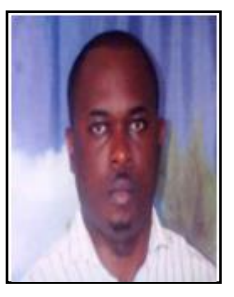

Samuel I. Egwunatum was born in Obiaruku, Delta State of Nigeria on the $31^{\text {st }}$ December, 1978. He had his degrees in Quantity Surveying from the Federal University of Technology, Akure, Nigeria in 2001 and 2015 specializing in Construction Economics.

, $\mathrm{He}$ had his compulsory paramilitary service to Nigeria in 2002.,He is currently a lecturer in Delta State Polytechnic, Ozoro.,He has published one textbook in Germany (Lost Labour Claims in Construction Projects: Principles and Estimation, by Lambert Academy Publishing, 2016). He has over twenty-one published articles in international reputable journals and patented two research output arising from his work (Nmorcha Threshold Operator and Egwunatum's Time Cost Equilibrial) which is currently being put together for a monograph.

Samuel Egwunatum is a member of the Nigerian Institute of Quantity Surveyors NIQS), Association for the Advancement of Cost Engineering (AACE) and American Society of Professional Estimators (ASPE).,He is a review editor to international journals and a consultant to the Delta State Government of Nigeria on Hydraform Mass Housing Project. 